\title{
PENANGGULANGAN DAMPAK NEGATIF AKSES INTERNET DI PONDOK PESANTREN MELALUI PROGRAM INTERNET SEHAT
}

\author{
Ahmad Budi Setiawan \\ Puslitbang APTIKA \& IKP, Badan Litbang SDM, \\ Kementerian Komunikasi dan Informatika, Jakarta 10110 Telp/Fax. 021-3800418 \\ email: ahmad.budi.setiawan@kominfo.go.id \\ Naskah diterima tanggal 25 Januari 2012, disetujui tanggal 9 April 2012
}

\section{OVERCOMING NEGATIVE IMPACT OF INTERNET ACCESS IN PONDOK PESANTREN THROUGH HEALHTY INTERNET PROGRAM}

\begin{abstract}
The presence of a healthy internet program initiated by the government and the communities who are concerned about the negative impact of the internet aims to campaign the use of the internet well and properly. The purpose of this study, to identify the application of the method of securing internet access for the students of the negative stuff in an attempt to socialize, and implements healthy internet empowerment program in pesantren. This research is a field research using descriptive method with qualitative approach. The results showed that the internet is not only used in a positive way, but also negative like accessing pornography site.
\end{abstract}

\section{Keyword: Healthy Internet Program, internet access, Boarding School}

\begin{abstract}
Abstrak
Hadirnya program internet sehat yang digagas oleh pemerintah dan komunitas yang peduli terhadap dampak negatif internet bertujuan untuk mengampanyekan penggunaan internet secara baik dan benar. Tujuan penelitian ini, untuk mengidentifikasi penerapan metode pengamanan akses internet bagi para santri dari hal-hal negatif dalam upaya untuk menyosialisasikan, dan mengimplementasikan program pemberdayaan internet sehat di kalangan pesantren. Penelitian ini merupakan penelitian lapangan dengan menggunakan metode deskriptif dengan pendekatan kualitatif. Hasil penelitian menunjukkan bahwa internet tidak hanya dimanfaatkan secara positif namun juga negatif seperti mengakses situs pornografi.
\end{abstract}

Kata Kunci: Program Internet Sehat, akses internet, Pondok Pesantren

\section{PENDAHULUAN}

Saat ini ketergantungan terhadap akses internet pada masyarakat semakin besar. Akses internet dibutuhkan bukan hanya bagi kalangan pelajar umum tapi juga di Pondok
Pesantren, yang dikenal dengan sebutan santri. Selama ini kalangan pesantren diasumsikan tertutup dengan perkembangan teknologi, terutama pesantren-pesantren yang bermazhab salafy yaitu pesantren yang fokus mempelajari kitab kuning. Berdasarkan hal 
tersebut, banyak masyarakat awam yang berasumsi bahwa pendidikan pesantren cenderung tertinggal dalam bidang pemanfaatan dan pembelajaran teknologi informasi, meski perlu didiskusikan. Asumsi tersebut saat ini sangat jauh dari kenyataan yang ada. Hal ini disebabkan karena sudah banyak bermunculan Pondok Pesantren modern yang mengadopsi kurikulum dan sistem pembelajaran di sekolah-sekolah umum dengan memanfaatkan teknologi informasi. Pada Pondok Pesantren modern tidak hanya fasilitas laboratorium modern seperti; laboratorium fisika, kimia, bahasa, dan semacamnya yang tersedia, tapi sudah banyak yang menambah fasilitas internet secara bebas untuk digunakan oleh santrinya. Antusiasme para santri terhadap teknologi internet belakangan ini disambut baik oleh petinggi pesantren yang mulai menyediakan fasilitas akses internet dan juga menggalakkan pelatihan internet. Mulai dari pemanfaatan internet hingga dampak positifnegatif dalam pemanfaatan internet. Banyak inovasi-inovasi yang telah dibuat para santri di Pondok Pesantren dalam memanfaatkan internet yakni (a). Internet dapat menjadi sarana dakwah secara online yang dikenal dengan istilah "syiar digital", (b). media untuk mempromosikan kegiatan dan produkproduk pendidikan Pondok Pesantren kepada masyarakat luas, (c). membentuk jejaring silaturahmi di antara para santri secara luas yang tidak dibatasi ruang dan waktu. Program ini sudah berjalan di berbagai Pondok Pesantren di Indonesia. Hadirnya internet di tengah pendidikan Pondok Pesantren diasumsikan dapat membawa solusi dan memberikan sumbangsih untuk kemajuan bagi santri. Dengan semakin memasyarakatnya internet maka dianggap bisa menjadi peluang pembelajaran di luar pendidikan formal pesantren.

Kesemua itu dilakukan untuk memacu semangat belajar para santri. Melalui internet, santri dapat men-download data-data yang diperlukan untuk bahan pembelajaran. Misalnya dengan teknologi mesin pencari (search engine) yang lazim digunakan, yaitu Google. Kebutuhan dalam segi keilmuan santri semakin meningkat dengan mesin pencari ini. Selain itu, internet dapat berfungsi sebagai perpustakaan on-line. Internet, memungkinkan santri dapat mengakses sumber informasi yang sudah tersedia. Internet dapat dijadikan sebagai sumber informasi sekunder untuk belajar. Internet telah "menggugurkan" masalah kelangkaan sumber informasi (perpustakaan) konvensional, yang selama ini menjadi masalah pesantren. Internet juga menghilangkan batas ruang dan waktu sehingga memungkikan seorang santri berkomunikasi dengan pakar di tempat lain. Dari berbagai persoalan seperti yang telah dipaparkan di atas, maka dibutuhkan sebuah kajian penelitian untuk menemukan solusi dan inovasi mengenai pemanfaatan internet bagi santri di kalangan Pondok Pesantren.

Pembahasan mengenai pemanfaatan internet sehat di kalangan Pondok Pesantren merupakan refleksi kenyataan yang ada sekarang. Internet dapat menjadi sumber inspirasi yang sifatnya positif, meskipun bisa disalahgunakan. Upaya pemanfaatan internet bagi kalangan pesantren bukan tanpa risiko karena internet itu sendiri ibarat pisau bermata dua. Keberadaan sisi positif pemanfaatan internet juga tidak lepas dari adanya sisi negatif internet itu sendiri. Pada satu sisi, internet dapat memberikan nilai tambah dan manfaat besar bagi penggunanya akan tetapi pada sisi lain bisa menjadi bumerang oleh karena adanya dampak negatif dari internet itu sendiri. Dampak negatif tersebut di antaranya; pornografi, penyebaran virus secara tak terkendali, spyware \& SPAM, hadirnya situs yang bersifat provokasi, adu domba, dan fitnah (black campaign) dan lainnya. Hal negatif yang dikhawatirkan para pendidik, pengajar khususnya dari kalangan Pondok Pesantren yaitu akses pornografi melalui internet. Melalui internet, pengguna termasuk para santri dimungkinkan bisa mengakses situs-situs porno dan mendapatkan file gambar atau video porno. Hal ini menjadi ironi karena sistem pendidikan Pondok Pesantren mengharamkan hal itu. Disamping itu yang tidak kalah menariknya dengan permasalahan pornografi, yaitu kekerasan dalam dunia maya atau yang dikenal dengan istilah cyber bullying. Dalam penelitian ini, 
akan dilihat bagaimana pemanfaatan internet dalam mendukung proses belajar-mengajar di Pondok Pesantren. Aspek yang menjadi perhatian dalam penelitian ini adalah bagaimana cara pengelola Pondok Pesantren mengamankan dampak negatif akses internet kepada para santri. Oleh karena itu, pertanyaan yang muncul dalam penelitian ini, adalah; "Bagaimana penerapan metode pengamanan akses internet untuk menangkal dampak negatif (baik secara teknik dan sosial) dalam upaya pemberdayaan program "internet sehat" di lingkungan Pondok Pesantren.

Penelitian ini pada dasarnya bertujuan untuk membuat gambaran deskriptif mengenai Pondok Pesantren Darur Ridwan, Parangharjo, Banyuwangi, Jawa Timur. Disamping itu juga untuk mengidentifikasi bagaimana penerapan metode pengamanan akses internet bagi para santri dari hal-hal negatif dalam upaya untuk menyosialisasikan dan mengimplementasikan program pemberdayaan internet sehat di kalangan pesantren.

Laporan ini secara khusus, diharapkan akan menghasilkan rumusan hasil penelitian ini dapat digunakan sebagai rekomendasi bagi Kementerian Kominfo dalam program pemberdayaan internet sehati Dirjen Aplikasi Informatika. Secara umum, hasil penelitian ini dapat digunakan sebagai referensi bagi para pengelola Pondok Pesantren untuk meningkatkan daya saing dan mutu serta kualitas Pondok Pesantren dengan memanfaatkan internet secara sehat dan aman untuk para santriwan/wati di lingkungan Pondok Pesantren.

\section{KERANGKA KONSEP}

\section{Program Internet Sehat dan Aman}

Secara sederhana, literasi gerakan internet sehat merupakan kepedulian masyarakat terhadap dampak buruk dari media, khususnya media baru melalui jaringan internet. Perkembangan internet, disamping memberikan manfaat untuk kehidupan manusia juga berdampak lain yang kurang baik. Beberapa dampak tersebut antara lain; (1) mengurangi tingkat privasi individu, (2) meningkatkan kecenderungan potensi kriminal, (3) anggota suatu komunitas akan sulit dibatasi mengenai apa yang dilihat dan didengarnya, (4) Intenet memengaruhi masyarakat madani dan kohesi sosial, (5) Terjadi overload-nya informasi. Tujuan literasi gerakan internet sehat ialah mengajar khalayak dan pengguna internet menganalisis pesan yang disampaikan, mempertimbangkan tujuan komersil dan politik dibalik citra atau pesan di internet dan meneliti siapa yang bertanggungjawab atas pesan yang diimplikasikan itu. Agar literasi gerakan internet sehat dapat berjalan dengan optimal diperlukan pendidikan berinternet (literasi internet sehat), yang mencakup: pendidikan etika berinternet, dan sejenisnya. Tujuannya untuk mengembangkan "literasi" internet sehat berbasis luas, yang tidak hanya berkenaan dengan internet saja tetapi juga untuk media cetak, media massa, dan internet. Pendidikan internet berkenaan dengan pembelajaran tentang etika bermedia internet, bukan pengajaran melalui media. Pendidikan etika bermedia internet bertujuan untuk mengembangkan baik pemahaman kritis maupun partisipasi aktif, sehingga anak muda sebagai konsumen media internet memiliki kemampuan dalam membuat membuat tafsiran dan penilaian berdasarkan informasi yang diperolehnya. Selain itu anak muda mampu menjadi produser media internet dengan caranya sendiri sehingga menjadi partisipan yang berdaya di komunitasnya.

Pendidikan bermedia internet adalah pengembangan kemampuan kritis dan kreatif anak muda. Sementara itu, sesuai dengan deklarasi UNESCO mengenai pendidikan media (UNESCO: 2006), terdapat beberapa konsep mengenai pendidikan media. Konsep tersebut bertujuan untuk mendorong pendidikan media secara komprehensif mulai tingkat prasekolah sampai perguruan tinggi, pendidikan orang dewasa yang bertujuan untuk mengembangkan pengetahuan, keterampilan dan sikap, kesadaran kritis. Pendidikan semacam ini juga untuk melahirkan kompetensi yang lebih besar di kalangan pengguna media cetak, elektronik, 
dan internet. Idealnya, program seperti ini mencakup analisis produk media, penggunaan media sebagai sarana ekspresi kreatif, serta memanfaatkan secara efektif dan berpartisipatif dalam saluran media. Mengembangkan pelatihan tokoh masyarakat (intermediaries) untuk meningkatkan pengetahuan dan pemahaman terhadap media internet. Mendorong kegiatan penelitian dan pengembangan untuk meningkatkan manfaat gerakan internet sehat, dalam bidang-bidang psikologi, sosiologi, dan ilmu komunikasi. Program ini merupakan suatu gerakan sosial yang berbasis komunitas masyarakat. Belum banyak penelitian yang menyebutkan tingkat literasi internet sehat (melek internet) di Indonesia, sehingga tetap diperlukan literasi media baru tersebut. Tingkat literasi biasanya berhubungan dengan tingkat pendidikan dan daya kritis masyarakat. Semakin tinggi pendidikan dan daya kritis seseorang semakin tinggi tingkat literasinya. Perilaku masyarakat terhadap literasi internet sehat bisa terbelah menjadi dua, yakni masyarakat pasif dan aktif. Biasanya jumlah masyarakat pasif lebih besar dibanding yang aktif. Mereka berperilaku diam menerima informasi dari media apapun, termasuk internet, bahkan tidak jarang tampak seperti tidak berdaya (Keith, 2003). Perilaku mereka Ini bagaikan Teori Jarum Hipodermik. Begitu disuntik pesan komunikasi, isinya segera menjalar keseluruh tubuh. Atas keperkasaan internet seolah-olah masyarakat konsumen menjadi tidak berdaya menghadapinya. Mereka mendapatkan informasi seperti masuk telinga kiri segera dikeluarkan lewat telinga kanan. Tetapi bagi mereka yang aktif selain berinteraksi dengan sesamanya juga mengritisi asal informasi. Mereka ini sadarinternet atau sering disebut tidak gaptek. Sedikitnya, jika memperhatikan teori di atas, tubuh pasien (khalayak) mengadakan "perlawanan", tidak menyerah begitu saja pada obat dan jarum suntiknya.

Saat ini masyarakat aktif tidak sekedar sebagai pemerhati atau pengamat tapi aktif melakukan sesuatu jika media telah melakukan penyimpangan. Penyimpangan ini bisa mengenai informasinya salah, kurang tepat, tidak seimbang, dan berdampak buruk bagi masyarakat. Masyarakat masih banyak yang belum tahu hak-haknya ketika mereka dijadikan objek pemberitaan yang merugikan dirinya. Tanpa adanya literasi berinternet masyarakat cenderung lemah dalam menghadapi media baru yang cenderung kapitalistik. Mereka hanya bisa mengonsumsi tetapi tidak tahu harus berbuat apa ketika media/internet yang mereka konsumsi merugikan. Masyarakat sebagai konsumen di satu sisi perlu mendapatkan informasi yang bermanfaat, dan di sisi lain juga penting untuk mendapatkan perlindungan. Model pembelajaran melalui literasi internet sehat ini dalam jangka panjang akan memberikan penguatan kepada masyarakat sebagai konsumen. Dengan konsep tersebut masyarakat tidak sekedar menjadi objek, tetapi sebagai subjek. Tetapi model literasi gerakan internet sehat tidak bisa diharapkan dalam jangka pendek, karena baru bisa dipetik hasilnya setelah dua generasi, dan seterusnya.

\section{Sistem Keamanan Akses Jaringan Internet}

Dampak isu negatif pemanfaatan internet di kalangan santri Pondok Pesantren telah menjadi kekhawatiran bagi para pengasuh Pondok Pesantren. Salah satu kasus pemanfaatan internet untuk keperluan negatif di kalangan santri yang paling banyak ditemukan adalah akses situs pornografi di internet. Secara umum, pornografi di internet sudah menjadi isu yang banyak dibicarakan masyarakat. Kondisi ini juga membuat prihatin masyarakat pada umumnya dan khususnya bagi pihak pendidik serta orang tua karena dapat merusak moral. Untuk itu para pengelola akses jaringan internet Pondok Pesantren yang menyediakan akses internet untuk keperluan operasional Pondok Pesantren melakukan upaya utnuk menangkal penyebaran situs-situs negatif tersebut. Salah satu metode penangkal penyebaran situs negatif adalah dengan cara content filtering. Proses penyaringan akses web dengan teknik content filtering memiliki beberapa metode penyaringan (Direktorat SIPLK, 2008), yaitu: (a). Domain Level Filtering; Penyaringan terhadap top-level domain. (b). URL Level 


\section{Gambar 2}

Arsitektur Content Filtering

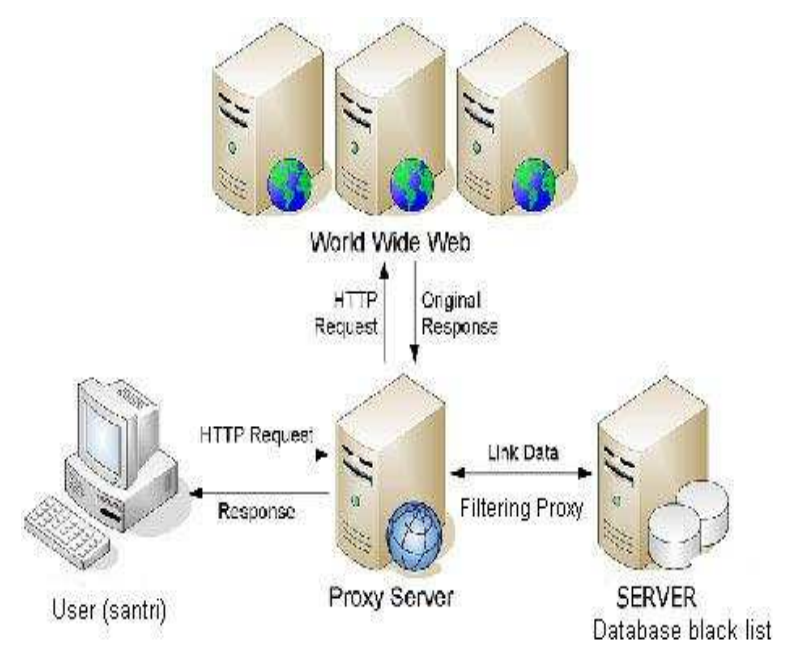

Sumber : Direktorat SIPLK, 2008

Gambar 3

Alur Proses Content Filtering

Sumber : Direktorat SIPLK, 2008

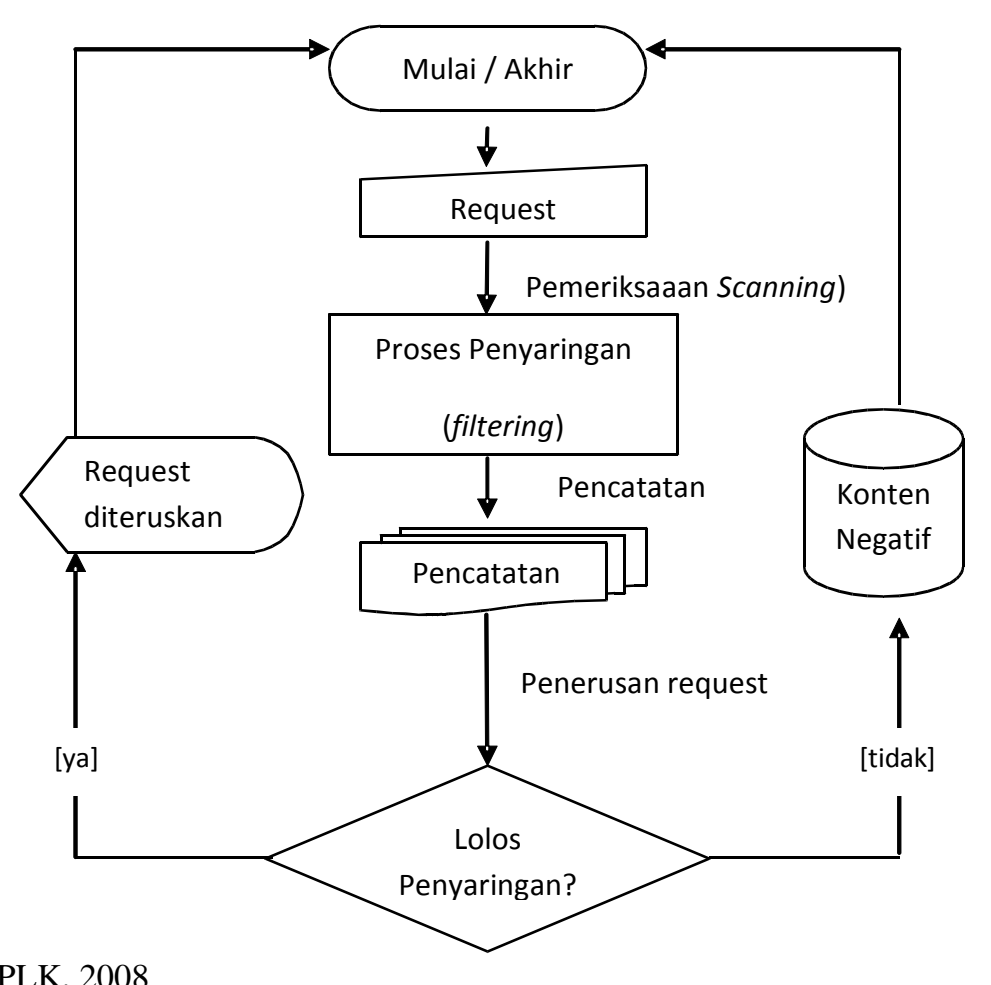

Filtering; penyaringan terhadap URL (Uniform Resource Locator), (c). Expression Filtering; penyaringan terhadap kata tertentu di dalam halaman web. Berikut ini dijelaskan alur proses content filtering yang dilakukan pada proxy server jaringan Local Area Network Pondok Pesantren;
Tenik penyaringan melalui content filtering dapat mengefisiensikan penggunaan bandwidth internet dengan cara mengarahkan konten yang tersaring ke website lokal untuk mengefisiensikan penggunaan bandwidth. Sistem ini terkontrol dengan cara melakukan proses kontrol dan memberikan laporan 
secara berkala. Daftar (list) database situs konten negatif kepada seluruh user internet (santri) dibagikan secara merata.

Teknik content filtering bekerja dengan cara menginventarisir dan menyimpan database situs yang dianggap memiliki konten negatif. Database akan senantiasa di up-date baik secara otomatis maupun secara manual. Melalui database ini selanjutnya proses content filtering akan melakukan penyaringan. Jika ada situs yang dianggap memiliki konten negatif dan masuk ke dalam daftar tangkal (black-list), maka situs tersebut tidak akan dapat diakses oleh para santri pengguna (user) internet. Situs tersebut secara sendirinya akan terblokir melalui sistem. Sebaliknya jika situs yang diakses oleh para santri tidak termasuk dalam black-list, maka situs tersebut dapat dan diperbolehkan untuk diakses.

\section{LANDASAN KONSEP}

\section{Pendidikan Pondok Pesantren mengharuskan para santrinya untuk} bermukim pada asrama Pondok Pesantren. Hadirnya internet diasumsikan dapat memenuhi kebutuhan informasi bagi para santri yang bermukim di Pondok Pesantren dan membantu mempercepat perkembangan pendidikan di Pondok Pesantren. Para santri siap menerima tantangan pendidikan modern yang berbasis teknologi informasi. Teknologi Informasi dan Komunikasi (TIK) telah mengalami perkembangan pesat. Hadirnya internet merupakan salah satu bentuk dari perkembangan TIK. Internet mampu menghubungkan hampir semua komputer di dunia sehingga dapat saling berkomunikasi dan bertukar informasi. Pemanfaatan internet dalam proses pendidikan pun telah mengalami perkembangan, dari pertukaran informasi secara elektronik ke strategi $e$ learning, seperti: e-library, e-education, eadministration, dan lain sebagainya. Internet mendukung komunikasi antara pengajar, pelajar, pihak pengelola pendidikan, dan masyarakat yang lain.

Keamanan akses internet memiliki empat macam tujuan yang sangat mendasar
(Purbo, 2003), yaitu: (1). Confidentiality; menjamin informasi yang disebarkan melalui internet tidak dapat diketahui oleh pihak lain yang tidak berkepentingan dan tidak memiliki hak untuk mengaksesnya. (2). Integrity; menjamin konsistensi keutuhan dan keaslian data yang disebar melalui internet. (3). Availability; sebuah jaminan bahwa data dan informasi yang disebar melalui internet diakses oleh pengguna yang sah dan benar memiliki hak untuk mengakses data dan informasi tersebut. (4). Legitimate Use; jaminan kepastian bahwa data dan informasi yang disebar melalui internet tidak diakses oleh pihak-pihak yang tidak bertanggungjawab.

Dalam keamanan akses internet, ada beberapa faktor yang harus diperhatikan baik oleh pihak pengelola internet ataupun oleh pengguna langsung (end user) internet (Purbo\& Wahyudi, 2001), yaitu; (1). Keamanan infrastruktur; yaitu aspek keamanan ditinjau dari perangkat keras yang menunjang akses internet dan keberadaan perangkat lunak yang dapat menangkal damapak negatif internet seperti; program anti virus, anti SPAM serta program filter situs asusila. (2). Keamanan personal; hal ini menyangkut kesadaran pribadi orang yang mengakses internet (end user) untuk menghindari dampak negatif pemanfaatan internet. (3). Keamanan administratif; merupakan peran aktif pihak pengelola jaringan internet (network administrator) dalam menangkal dampak negatif pemanfaatan internet. Faktor-faktor kemaman akses internet tersebut bersifat mendasar dan tidak dapat dianggap sepele. Kontrol pengelola akses jaringan internet menjadi sangat utama. Jaringan internet merupakan jaringan publik dimana setiap khalayak yang menggunakannya dapat dengan bebas mengakses situs apa pun. Tanpa adanya kontrol akses terhadap pemanfaatan internet, pengguna internet dapat menggunakannya ke arah penggunaan yang negatif seperti membuka situs-situs asusila, dan lain sebagainya.

Kontrol akses internet untuk mencegah adanya pemanfaatan internet yang berdampak negatif dapat dilakukan dengan 
cara melakukan proses content filtering pada server jaringan. Hal lain yang dapat dilakukan adalah dengan menginstalasikan sistem firewall pada proxy server. Pemanfaatan internet yang aman dan sehat dengan teknik content filtering dilakukan dengan menggunakan metode penyaringan (Direktorat e-Business, 2009): Domain Level Filtering; Penyaringan terhadap top-level domain. URL Level Filtering; Penyaringan terhadap URL. Expansion Filtering; Penyaringan terhadap kata tertentu di dalam halaman web. Banyak hal yang dapat diupayakan untuk mengamankan akses internet dari dampak negatif dengan cara memperhatikan faktor-faktor, di antaranya; infrastruktur, personal (end user), dan juga administratif. Selain itu pihak pengelola juga perlu mengetahui langkah-langkah dalam melakukan kontrol terhadap akses internet dan membuat kebijakan yang dapat diimplemenatsikan untuk pengguna internet. Dengan demikian pengguna diharapkan dapat memanfaatkan internet secara sehat dan aman.

\section{METODE PENELITIAN}

Penelitian ini, menggunakan metode deskriptif dengan pendekatan kualitatif. Teknik pengumpulan data dilakukan melalui observasi langsung dan wawancara mendalam. Data yang akan diperoleh melalui observasi dan wawancara mendalam adalah data mengenai pemanfaatan internet di kalangan Pondok Pesantren, sedangkan metode pengamanan akses internet yang dilakukan pada pengelola pesantren khususnya pengelola TI pada Pondok Pesantren yang bersangkutan. Unit analisis yang digunakan dalam penelitian ini, antara lain; keamanan infrastruktur, meliputi; metode akses internet dan topologi jaringan internet yang diterapkan serta keberadaan perangkat lunak penangkal dampak negatif internet. Keamanan personal, meliputi; perilaku dan kebiasaan santri sebagai pengguna internet (end user) dalam memanfaatkan internet. Keamanan administratif, meliputi; peran aktif pihak pengelola jaringan internet (network administrator) dalam menangkal dampak negatif pemanfaatan internet. Pengambilan sampel dilakukan menggunakan purposif sampling yang bisa juga berkembang menjadi snowball sampling. Dimana narasumber yang dituju adalah pengelola pondok pesantren dan pengelola bagian TI yang menangani akses internet pada pondok pesantren yang bersangkutan. Lalu wawancara dilanjutkan kepada para pengguna di kalangan pondok pesantren, yaitu beberapa santri yang aktif memanfaatkan internet. Penunjukkan santri yang akan diwawancarai adalah dengan cara random sampling.

\section{HASIL PENELITIAN DAN PEMBAHASAN}

\section{Pemanfaatan Internet di Kalangan Santri}

Saat ini, akses internet sudah menjadi salah satu kebutuhan masyarakat. Jaringannya pun sudah menjangkau hingga ke pelosok desa. Dalam bidang pendidikan, internet juga sudah mulai dimanfaatkan oleh Pondok Pesantren dalam menunjang aktivitas harian, meski masih banyak juga Pondok Pesantren yang belum memanfaatkan internet. Dalam hal pemanfaatan internet, profil pemanfaatan internet pada Pondok Pesantren dapat dibagi menjadi tiga jenis, yaitu;

a. Pondok Pesantren yang memanfaatkan internet sepenuhnya untuk menunjang aktivitas Pondok Pesantren baik untuk keperluan administratif maupun untuk keperluan belajar-mengajar.

b. Pondok Pesantren yang memanfaatkan internet secara sebagian, yaitu hanya untuk keperluan adminstratif saja, sedangkan santri secara umum tidak diperkenankan untuk memanfaatkan internet dengan alasan tertentu. Jika santri ingin menggunakan internet harus dengan proses perizinan yang ketat.

c. Pondok Pesantren yang tidak menyediakan fasilitas intenet dan tidak memanfaatkan internet sama sekali dalam segala kegiatan operasional, baik administratif maupun untuk kegiatan 
belajar-mengajar.

Internet dimanfaatkan oleh beberapa Pondok Pesantren untuk penunjang kegiatan administratif, seperti untuk promosi Pondok Pesantren dengan pembuatan website resmi Pondok Pesantren, untuk tukar-menukar informasi atau data melalui e-mail dengan berbagai pihak yang terkait dengan Pondok Pesantren. Pada Pondok Pesantren yang memanfaatkan internet untuk proses belajarmengajar santri, internet digunakan untuk mencari informasi yang dibutuhkan santri dalam proses belajar. Pengamanan akses internet dilakukan secara sederhana, antara lain dengan cara pemblokiran situs-situs negatif dan situs-situs yang dianggap mengganggu dalam proses belajar santri.

Keberadaan internet seakan telah mengubah hampir seluruh aspek kehidupan masyarakat termasuk pola kerja dan belajar. Tidak hanya pola belajar pada siswa-siswi di sekolah umum (SD, SMP, SMA) tetapi juga pola belajar santri pondok pesantren. Semangat belajar santri yang cenderung lebih tinggi ketimbang siswa dari lembaga pendidikan umum dan motivasi secara terusmenerus dari para pengajar pondok pesantren (asatidz), membuat internet di kalangan santri menjadi cukup populer. Pada pondok pesantren yang telah mengadopsi pola pendidikan modern dan menggabungkan antara kurikulum pondok dan kurikulum pendidikan formal, internet diperkenalkan dan dipergunakan oleh para santri secara bebas tapi terkontrol. Antusiasme para santri terhadap internet yang telah mengadopsi pendidikan modern disambut baik dengan inovasi-inovasi petinggi pesantren yang mulai menggalakkan pelatihan internet, mulai dari pemanfaatan internet hingga plus-minus internet dan ditambah lagi hal tersebut semakin didukung oleh pengurus Pondok Pesantren setempat. Internet merupakan sebuah perpustakaan maya (virtual library) yang mengandung jutaan data dan informasi tentang berbagai hal. Salah satunya termasuk berbagai data dan informasi tentang pendidikan. Internet dapat dijadikan sebagai salah satu sumber ilmu alternatif bagi kalangan pendidikan di Pondok Pesantren disamping adanya perpustakaan konvensional di Pondok Pesantren terkait.

Berdasarkan hasil observasi melalui wawancara dengan beberapa narasumber Selain itu manfaat yang ditimbulkan dari kehadiran internet bagi pendidikan khususnya pesantren antara lain:

1. Mempercepat dan mempermudah alih ilmu pengetahuan dan teknologi.

2. Proses pembelajaran lebih menarik. Melalui internet pembelajaran tidak monoton dan jenuh karena dalam internet ada hal-hal baru yang variatif dan inovatif.

3. Mendorong para santri untuk lebih aktif mencari ilmu pengetahuan dan informasi.

4. Mempermudah penjelasan konsep. Metode pembelajaran di pondok pesantren, umumnya materi atau bahan pelajaran selalu disampaikan melalui metode ceramah. Dengan adanya internet, ustaz dapat menyampaikan konsep atau materi secara audiovisual. Pelajaran lebih nyata dan jelas, sehingga mempermudah pemahaman santri.

5. Pembelajaran lebih konseptual dan up-todate (aktual). Mata pelajaran yang akan disampaikan kepada santri bisa menyesuaikan dengan kondisi aktual. Dengan demikian konsep-konsep yang diajarkan dapat disesuaikan dengan kondisi terkini.

6. Mempermudah dan mempercepat administrasi pendidikan. Pelaksanaan proses pendidikan harus diusahakan lebih praktis dan cepat. Ustaz tidak terlalu disibukkan dengan urusan administrasi yang berbelit-belit, sehingga konsentrasi lebih tertuju pada proses pembelajaran di kelas. Misalnya, dalam membuat persiapan mengajar, pengolahan nilai, dan menyebarluaskan nilai ulangan atau ujian, bisa menggunakan fasilitas komputer (internet). Dengan demikian, internet dapat memperbaiki dan memperlancar administrasi pendidikan.

7. Sebagai perpustakaan elektronik.

8. Mempercepat dan mempermudah komunikasi edukatif antara ustaz dengan santri.

Keberadaan internet diharapkan dapat 
membantu mempercepat perkembangan pendidikan di Pondok Pesantren, pendidikan yang lebih maju dan berkualitas. Pada gilirannya Pondok Pesantren dapat membantu mencerdaskan kehidupan bangsa. Bangsa yang cerdas akan membantu meningkatkan kesejahteraan rakyat. Hal tersebut merupakan suatu refleksi kenyataan yang terjadi di lingkungan Pondok Pesantren saat ini. Pemanfaatan internet dapat menjadi sumber inspirasi yang bersifat positif meskipun terkadang internet masih disalahgunakan untuk akses negatif.

\section{Kategorisasi Pemanfaatan Internet Pada Pondok Pesantren}

Berdasarkan hasil observasi yang dilakukan, didapatkan tiga jenis Pondok Pesantren dalam hal pemanfaatan internet dalam aktivitas dan operasional Pondok Pesantren baik dalam hal administratif ataupun kegiatan belajar-mengajar. Ketiga jenis pesantren tersebut memiliki model pemanfaatan yang berbeda-beda. Jenis Pondok Pesantren yang pertama, yaitu Pondok Pesantren yang memanfaatkan internet secara keseluruhan. Jenis yang kedua, yaitu Pondok Pesantren yang memanfaatkan internet untuk kegiatan administratif Pondok Pesantren dan jenis yang terakhir adalah Pondok Pesantren yang tidak memanfaatkan fasilitas akses internet sama sekali.

Pada Pondok Pesantren jenis yang pertama, akses internet tidak hanya untuk keperluan operasional administratif Pondok Pesantren, akan tetapi fasilitas internet untuk dapat diakses oleh para santrinya. Menurut Ust. Abu Mansyur, penanggungjawab infrastruktur IT dan laboratorium komputer, Pondok Pesantren Hidayatullah, Surabaya (11/4/2011); Teknologi Informasi (TI) dalam wujud jaringan internet, pada mulanya dimanfaatkan Pondok Pesantren untuk keperluan administrasi. Internet dimanfaatkan untuk keperluan promosi Pondok Pesantren, keperluan para pengajar (ustaz dan ustazah) dan pegawai Pondok Pesantren untuk memback-up materi ajar dan pengolahan data. Pada perkembangan selanjutnya, internet juga dimanfaatkan untuk keperluan belajarmengajar para santri. Pemanfaatan internet pada Pondok Pesantren Hidayatullah sudah diberlakukan secara umum kepada para penghuni Pondok Pesantren. Menurut Ust. Abu Mansyur (11/4/2011); awalnya, akses internet hanya diberikan pada saat mata pelajaran komputer dan internet di laboratorium komputer. Selanjutnya, akses internet diberikan secara bebas kepada para penghuni Pondok Pesantren. Internet dapat diakses bukan hanya pada laboratorium komputer melalui jaringan kabel, namun internet dapat diakses melalui jaringan nirkabel (wi-fi) yang disediakan pihak Pondok Pesantren Hidayatullah. Pondok Pesantren Hidayatullah menyediakan 5 (lima) titik hot spot di lingkungan Pondok Pesantren. Setiap komputer yang berada di lingkungan Pondok Pesantren terhubung dalam satu jaringan lokal maka jaringan tersebut berjenis LAN (Local Area Network). Jaringan LAN Pondok Pesantren terakses ke internet melalui sebuah server. Topologi jaringan internet yang digunakan pada Pondok Pesantren adalah menggunakan topologi star. Menurut Ust. Abu Mansyur (11/4/2011), jaringan internet pada Pondok Pesantren yang dikelolanya memiliki topologi star network dan memiliki tiga buah server, yaitu; Web Server, Proxy Server. Jangkauan wi-fi pada Pondok Pesantren dapat menjangkau sejauh radius $500 \mathrm{~m}$. Pada contoh Pondok Pesantren modern lainnya, Pondok Pesantren Amantul Ummah, Wonocolo, Surabaya, internet dimanfaatkan untuk keperluan administratif dan untuk promosi Pondok Pesantren. Pemanfaatan internet dalam hal administratif meliputi surat-menyurat dan pertukaran data dengan media surat elektronis (e-mail). Menurut pengasuh Pondok Pesantren Ammanatul Ummah, Ust. Muthiullah (13/4/2011), korespondensi dengan pengurus cabang Pondok Pesantren Ammanatul Ummah, yaitu Pondok Pesantren Nurul Ummah yang berada di Mojokerto melalui $e$ mail menjadi sangat efektif dan efisien. Melalui e-mail pesan/surat dan data yang dikirim tidak perlu menunggu jawaban berhari-hari. 


\section{Gambar 4}

Arsitektur Jaringan LAN dan Akses Internet Pondok Pesantren

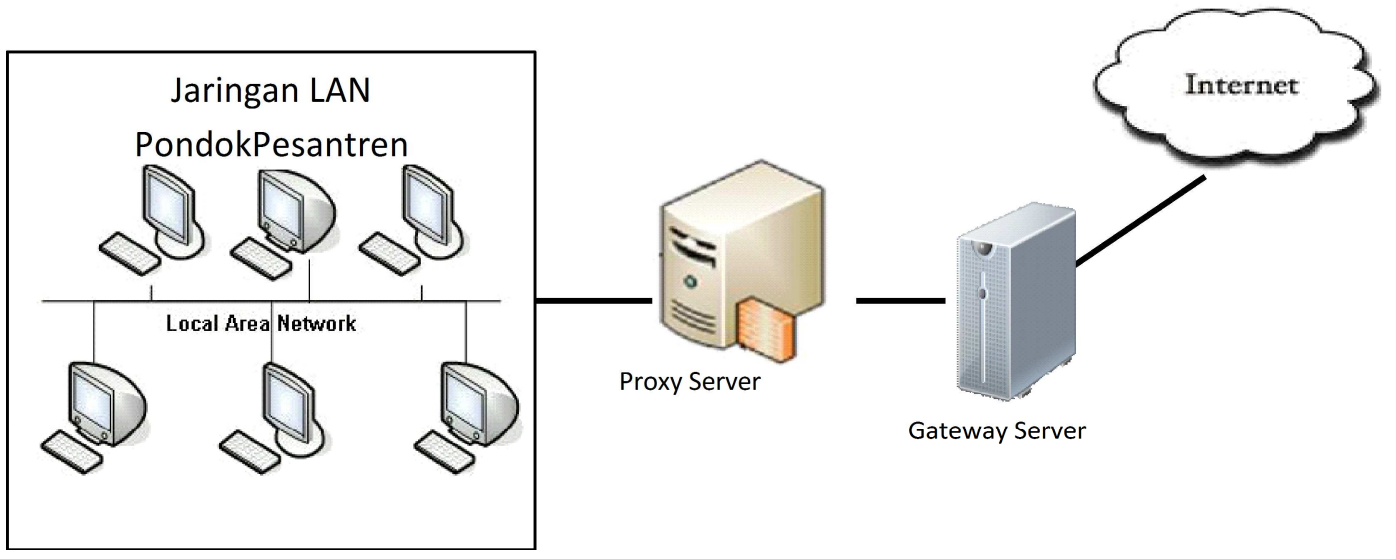

Sumber : Hasil Penelitian

Ust. Muthiullah (13/4/2011) juga menyampaikan, bahwa Pondok Pesantren Ammanatul Ummah, selain menyajikan pendidikan kurikulum agama Islam yang mengikuti kurikulum pendidikan menengah dari Al-Azhar, Kairo, Mesir juga menyajikan pendidikan kurikulum Kementerian Pendidikan Nasional (Diknas). Dengan demikian Pondok Pesantren di bawah pimpinan Dr. KH.Asep Saifuddin Chalim, MA ini perlu menyetarakan dan menyamakan pendidikan pondok dengan pendidikan formal di luar Pondok Pesantren. Oleh karena itu, para santri diberikan akses internet selama berada di area sekolah, namun di dalam asrama akses internet bagi santri tidak diperbolehkan. Hal ini dilakukan agar santri tidak dapat mengakses situs-situs negatif selama berada dalam masa pendidikan. Akses internet di asrama sangat sulit dikontrol, namun akses internet di area sekolah dapat dikontrol oleh pengelola jaringan internet.

Akses internet di asrama hanya diperbolehkan bagi santri kelas akhir untuk keperluan belajar dan pencarian data tugas akhir yang diberikan pondok serta untuk mencari beasiswa sekolah tinggi. Akses internet pada asrama juga diperbolehkan untuk pengurus organisasi santri dalam kegiatan tertentu. Di luar itu semua, akses internet di asrama tidak diperbolehkan. Penyelenggaraan kegiatan belajar mengajar setiap hari terdiri dari 12 jam pelajaran yang dilaksanakan $06.45 \quad \mathrm{~s} / \mathrm{d} \quad 13.00$ materi kurikulum nasional: pukul 16.30 s/d 17.30 pengajaran Al-Qur'an diselenggarakan di seluruh kelas dan pukul 18.00 s/d 20.30 pembelajaran Kitab Muadalah. Kegiatan belajar sehari-hari penuh dibimbing dan dikontrol oleh pengasuh Pondok Pesantren Amanatul Ummah.

Pada Pondok Pesantren jenis pesantren yang kedua, pemanfaatan internet tidak diberikan kepada para santri selama dalam pengasuhan pondok pesatntren. Pemanfaatan internet hanya sebatas untuk keperluan administratif seperti; pertukaran data, pengiriman hatsilah (hasil suatu pembahasan masalah), surat-menyurat elektronis bagi pengurus Pondok Pesantren dan ada pula pengurus Pondok Pesantren yang memanfaatkan internet untuk proses transaksi pembayaran telepon, listrik, dan lain sebagainya secara elektronis. Akses internet juga dimanfaatkan oleh para pengajar santri untuk mencari referensi bahan mengajar dan data/informasi untuk bahan kajian. Model pemanfataan internet untuk keperluan administratif pada Pondok Pesantren jenis salafi, salah satunya dimanfaatkan pada Pondok Pesantren Mamba'ul Fallah, Surabaya dan Pondok Pesantren Al Khozny, Surabaya. Hal ini dikemukakan oleh Bapak KH. M. Ali Maghfur Sadzily (12/4/2011), Pengasuh Pondok Pesantren Mamba'ul Fallah dan Ust. Abdul Quddus (12/4/2011), Ketua 
Pondok Pesantren Al-Khozny. Kedua narasumber tersebut juga menambahkan bahwa pada Pondok Pesantren Salafi umumnya tidak disediakan sarana dan prasaran untuk akses internet bagi para santri. Santri yang bermukim di Pondok Pesantren Salafi mendapatkan pendidikan agama selepas Salat Magrib sampai pukul 21.00 menjelang jam istirahat malam. Dilanjutkan setelah salat Subuh selama 30 menit. Setelah itu para santri mengikuti kegiatan pendidikan formal di sekolah-sekolah umum sesuai dengan jenjang pendidikan masing-masing. Pada kedua Pondok Pesantren tersebut, sarana dan prasarana akses internet tidak disediakan karena akses internet tidak diperlukan dalam proses pembelajaran. Pada dasarnya pihak Pondok Pesantren tidak melarang para santri untuk mengakses internet. Para santri bisa mendapatkan akses internet di luar pesantren, seperti di sekolah atau mengunjungi warnet terdekat. Menurut Ust. Abdul Quddus dari Pondok Pesantren Al-Khozny (12/4/2011), akses internet hanya dibatasi bagi para santri selama berada dalam kawasan Pondok Pesantren. Hal ini dilakukan untuk menghindari dampak negatif pemanfaatan internet.

Pada Pondok Pesantren yang menyediakan fasilitas akses internet untuk para santri, memberikan pengetahuan khusus mengenai internet yang bersifat teknis dan juga non-teknis. Pengetahuan teknis meliputi pemahaman tentang teknologi internet itu sendiri, sedangkan pengetahuan non-teknis meliputi tata cara dan perilaku santri ketika mengakses internet serta dampak positif dan negatif pemanfaatan internet. Narasumber dari Pondok Pesantren Hidayatullah mengatakan bahwa santri mendapatkan pengajaran dan pemahaman mengenai IT secara khusus dan pemanfaatan internet secara sehat dari bagian sumber daya manusia Pondok Pesantren. Pengajaran dan pemahaman mengenai internet juga dilakukan pada pesantren objek penelitian lainnya yang juga menerapkan sistem pengajaran modern, yaitu pada Pondok Pesantren Amanatul Ummah. Menurut penanggung jawab laboratorium komputer dan jaringan internet Pondok Pesantren Amanatul Ummah, bapak
Nur Hafidz, pemahaman mengenai pemanfaatan internet secara sehat dilakukan bersamaan dengan pengajaran teknologi internet di kelas atau laboratorium komputer pada saat mata pelajaran bidang komputer. Disamping itu, pada kesempatan tertentu, pimpinan Pondok Pesantren juga memberikan nasihat kepada para santri mengenai dampak negatif keberadaan teknologi secara umum dan internet secara khususnya.

\section{Akses Internet di Kalangan Santri Pondok Pesantren}

Pada hakikatnya, akses internet yang disediakan oleh Pondok Pesantren adalah untuk keperluan proses pembelajaran santri. Menurut Ust. Abu Mansyur (11/4/2011), narasumber dari Pondok Pesantren Hidayatullah, akses internet disediakan oleh Pondok Pesantren bagi santri untuk keperluan belajar. Melalui internet, diharapkan santri dapat menambah khazanah ilmu mereka. Internet bagaikan sebuah perpustakaan, dimana di dalamnya terdapat berbagai ilmu yang dapat dipelajari. Narasumber dari Pondok Pesantren Amanatul Ummah, Ust. Muthiullah, juga mengatakan bahwa akses internet bagi para santri adalah untuk keperluan belajar. Selain dari perpustakaan, para santri juga dapat mencari tambahan referensi suatu ilmu melalui internet.

Di samping itu, bagi santri tingkat akhir, internet dimanfaatkan para santri untk mencari informasi mengenai pendidikan lanjutan setelah lulus dari pondok pesantren berikut pencarian beasiswa pendidikan. Akses internet bagi para santri tidak hanya dimanfaatkan untuk keperluan proses pembelajaran saja. Pada beberapa kasus di Pondok Pesantren Al-Muhyiddin, Surabaya, para santri memanfaatkan internet untuk bermain game on-line, chatting, dan situs jejaring sosial, seperti: facebook, friendster, twitter, dan lain sebagainya. Sebagaimana disampaikan oleh seorang narasumber, yaitu Ust. Hasan Badri (12/4/2011), pengurus Pondok Pesantren Al-Muhyiddin. Beliau menyampaikan bahwa para santri cenderung memanfaatkan internet untuk keperluan yang tidak penting seperti bermain game online, 
chatting, dan akses situs jejaring. Menurut narasumber, hal-hal tersebut pada dasarnya tidak diharamkan bahkan oleh agama sekalipun, namun sejak diberlakukannya akses internet bagi para santri, prestasi belajar para santri menjadi turun. Sebagian besar para santri pada Pondok Pesantren Al-Muhyiddin menjadi lalai dan prestasi belajar menurun dikarenakan fokus belajar menjadi terganggu dengan adanya akses internet. Sebelumnya, pada tahun 2007 hingga 2008, pihak Pondok Pesantren Al-Muhyiddin menyediakan akses internet bagi para santri. Awalnya akses internet bertujuan untuk mendukung proses belajar para santri. Akses internet diberikan pada laboratorium komputer Pondok Pesantren dan para santri diperbolehkan akses internet di luar jam belajar dan jam istirahat malam. Akan tetapi pada kurun waktu tersebut, pihak Pondok Pesantren merasakan adanya penurunan prestasi belajar para santri. Berdasarkan hal tersebut, saat ini Pondok Pesantren tidak lagi menyediakan akses internet untuk para santri.

Pemanfaatan internet lainnya di kalangan santri adalah dengan membentuk suatu komunitas atau grup di dunia maya. Hal ini dilakukan oleh para alumni santri Pondok Pesantren Al-Muhyiddin. Sebagaimana dikemukakan oleh narasumber dari pengasuh Pondok Pesantren Al-Muhyiddin, Ust. Hasan Badri (12/4/2011), para alumni dan beberapa santri juga memanfaatkan facebook untuk membuat sebuah komunitas/grup melalui facebook. Hal ini bertujuan untuk menjaga silaturahmi di antara keluarga besar pondok pesantern Al-Muhyiddin dan sebagai alat untuk penyebaran informasi di antara alumni dan santri yang efektif. Menurut Ust. Hasan Badri (12/4/2011), pemanfaatan internet untuk menjaga silaturahmi adalah bersifat positif, namun bagi santri aktif dapat mengakses internet ketika di luar kawasan Pondok Pesantren.

Pemanfaatan akses internet lainnya yang bernilai positif dikalangan santri selain untuk sarana pendukung belajar, juga dapat digunakan sebagai saranya dakwah atau syiar agama Islam. KH. Ali Maghfur Sadzily, selain berperan sebagai pengasuh Pondok Pesantren Mambaul Fallah juga dipercayai oleh sebuah organisasi Islam terbesar, yaitu Nahdhatul Ulama (NU) Cabang Surabaya sebagai sekretaris lembaga Bahtsul Matsail. Pada organisasi yang dikelolanya, banyak sekali dilakukan pengkajian-pengkajian tentang permasalahan agama Islam yang aktual di masyarakat. Beliau menyampaikan bahwa banyak sekali kebutuhan akan sumber-sumber ilmu agama Islam berupa tulisan para ulama besar dari luar negeri seperti dari Mesir, Saudi Arabia, dan negara Timur Tengah lainnya juga sumber-sumber berupa buku elektronis (e-book) kalangan ulama terkenal yang bisa didapat melalui internet (12/4/2011). Beliau juga menambahkan bahwa pada lembaga yang dikelolanya internet juga dimanfaatkan sebagai media dakwah. Hasil kajian yang telah dilakukan oleh Lembaga Bahtsul Matsail pimpinan cabang NU Surabaya yang dipublikasikan melalui internet, yaitu melalui situs www.solusinahdliyin.net. Hasil kajian tersebut dapat dijadikan rujukan karena merupakan bahasan dari ulama-ulama yang dianggap memiliki kepakaran dalam bidangnya.

Dengan demikian, menurut KH. M. Ali Maghfar Sadzily (12/4/2011), pada dasarnya internet memiliki banyak manfaat, namun pemanfaatannya perlu dibatasi dari penyalahgunaan internet yang negatif. Beliau juga menambahkan, para ulama dan NU memfatwakan internet haram untuk pemanfaatan yang negatif. Namun fatwa yang pernah dikeluarkan ini dipublikasikan salah oleh pihak media. Banyak media yang hanya menyampaikan fatwa tersebut secara tidak utuh kepada masyarakat. Banyak pemberitaan yang menyebutkan bahwa para ulama menyatakan pemanfaatan internet adalah haram. Dalam hal ini, haram yang dimaksudkan adalah haram untuk pemanfaatan negatif. Sementara di sisi lain, fatwa dari para ulama, umumnya dijadikan rujukan bagi umat Islam. Maka timbullah permasalahan baru, yaitu masyarakat beropini bahwa sebagian besar ulama mengharamkan pemanfaatan internet. Oleh karena itu, media harus berimbang, adil, dan jujur (fair) dalam memberitakan sikap para ulama dalam hal ini agar penerimaan masyarakat tidak simpang siur. 


\section{Dampak Negatif Akses Internet Pondok Pesantren}

Pemanfaatan internet di kalangan santri Pondok Pesantren seolah memiliki dua sisi. Disatu sisi, internet dapat bernilai sangat bermanfaat, namun disisi yang lain internet tidak lepas dari dampak negatif yang dimilikinya. Dampak negatif internet yang sangat dikhawatirkan oleh para pengasuh Pondok Pesantren adalah akses situs pornografi. Menurut Ust. Abu Mansyur (11/4/2011), narasumber dari Pondok Pesantren Al-Hidayah menyatakan bahwa pihak Pondok Pesantren sangat mengawatirkan akses situs pornografi di kalangan santri karena takut akan menjerumuskan akhlak dan moral para santri. Narasumber dari Pondok Pesantren Mamba'ul Fallah, KH. M. Ali Maghfur Sadzily (12/4/2011) juga menyatakan salah satu penyebab rusaknya moral generasi muda adalah merebaknya pornografi di masyarakat. Keberadaan internet dapat mempermudah akses masyarakat untuk mendapatkan hal-hal yang bersifat pornografi. Dampak negatif ini dapat dihindarkan apabila semua lapisan masyarakat, baik pemerintah, tokoh masyarakat, dan tokoh agama juga para orang tua peduli terhadap masalah tersebut dan mau menanggulanginya bersama.

Keberadaan game on-line dan situssitus jejaring sosial seperti facebook menjadikan para santri menjadi lalai dan menjadi candu dengan situs-situs tersebut. Hal ini serupa dengan keluhan yang disampaikan oleh Ust. Hasan Badri, pengasuh Pondok Pesantren Al-Muhyiddin (12/4/2011) bahwa para santri yang umumnya adalah anak-anak usia remaja belum siap menghadapi keberadaan internet dalam hal akses pornografi. Di samping itu keberadaan game on-line serta adanya situs jejaring sosial seperti facebook, friendster, twitter, dan lain sebagainya menjadikan para santri ketagihan (candu) dengan permainan tersebut. Dampak dari permasalahan tersebut adalah santri menjadi lalai dan mengakibatkan turunnya prestasi belajar para santri.

\section{Keamanan Akses Internet Pondok Pesantren}

Adanya dampak negatif internet memerlukan perhatian khusus bagi para pengasuh dan khususnya pengelola akses jaringan internet di lingkungan Pondok Pesantren. Tindakan preventif (pencegahan) terhadap dampak negatif akses internet di lingkungan Pondok Pesantren terdiri dari dua macam tindakan, yaitu secara teknis maupun non-teknis. Pencegahan secara teknis yang dilakukan pihak pengelola Pondok Pesantren adalah dengan melakukan tindakan teknis berupa pemblokiran situs-situs negatif melalui proses filtering situs negatif. Sedangkan pencegahan secara non-teknis adalah dengan melakukan tindakan berupa pengarahan-pengarahan (tausiyyah) melalui pengajian yang disampaikan oleh pengajar (ustaz) atau pempinan pondok (kyai) atau pengarahan pada saat pembelajaran di kelas.

$\begin{array}{cccc}\text { Pada } & \text { Pondok } & \text { Pesantren yang } \\ \text { menyediakan } & \text { akses } & \text { internet } & \text { untuk }\end{array}$
mendukung kegiatan operasional Pondok Pesantren, dilakukan kedua macam tindakan pencegahan tersebut. Menurut Ust. Abu Mansyur (11/4/2011), dari Pondok Pesantren Hidayatullah; untuk menghindari konten negatif, pengelola akses jaringan internet melakukan filtering (penyaringan) menggunakan perangkat lunak (software) khusus untuk menyaring konten negatif seperti, DNS Nawala dan Net Support. Perangkat lunak tersebut diinstalkan pada proxy server. Hal serupa juga dilakukan pada Pondok Pesantren lainnya yang menyediakan akses internet bagi santri, yaitu Pondok Pesantren Amantul Ummah. Menurut narasumber, pengelola laboratorium komputer dan internet, Ust. Nur Hafidz (13/4/2011); tindakan pencegahan terhadap situs negatif dengan cara memblokir situs-situs (website) yang berisikan konten negatif, sehingga santri tidak dapat mengakses situs-situs tersebut selama memanfaatkan akses internet di lingkungan Pondok Pesantren. Pada kedua Pondok Pesantren tersebut, seluruh akses internet di lingkungan Pondok Pesantren, baik yang terkoneksi dengan kabel ataupun nirkabel (wi-fi) harus melalui satu gateway server. 


\section{Gambar 5}

Content Filtering pada Jaringan LAN Pondok Pesantren

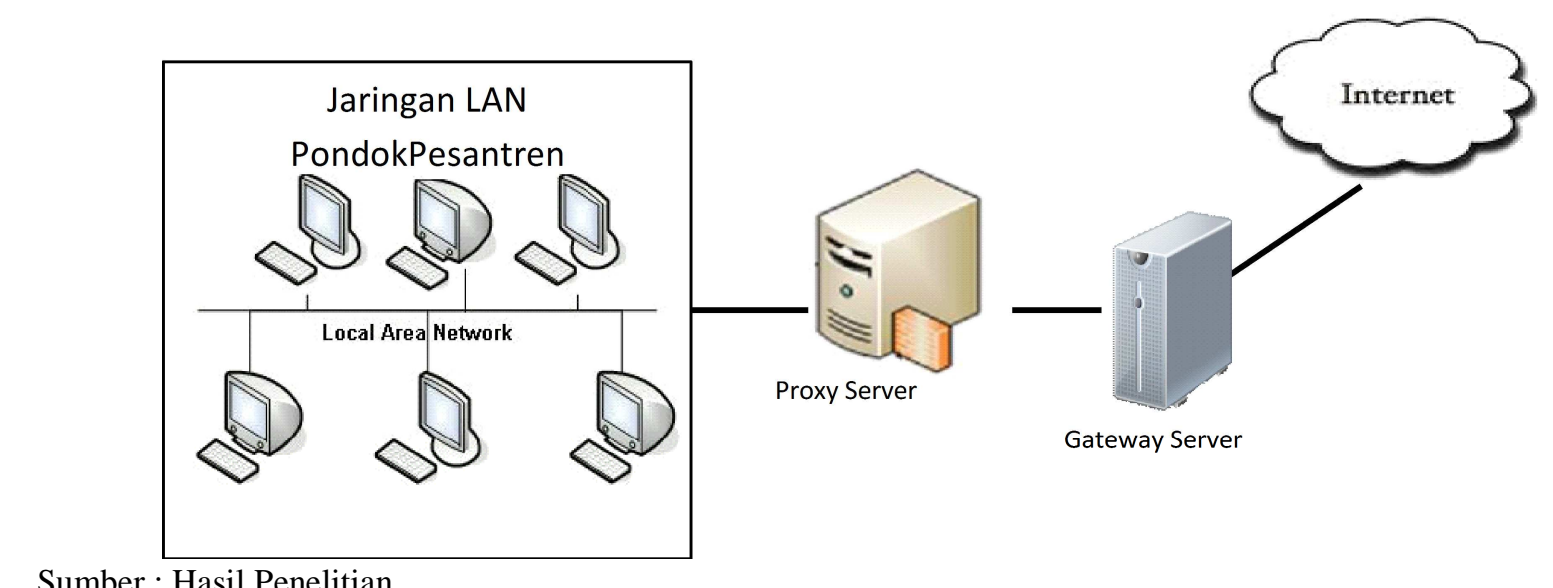

Sumber : Hasil Penelitian

Pada server tersebutlah dilakukan tindakan pemblokiran atau penyaringan terhadap situssitus yang dianggap negatif. Pada Pondok Pesantren Hidayatullah, menurut narasumber, Teknik filtering yang digunakan adalah dengan cara content filtering dengan metode penyaringan URL Level Filtering.

Dengan demikian, salah satu tugas pengelola jaringan internet adalah terusmenerus menginventarisir data alamat website yang dianggap memilki konten negatif. Data alamat website disimpan pada database situs internet yang dianggap mengandung konten negatif, dan selanjutnya dilakukan proses filtering (penyaringan). Data tersebut selalu dimutakhirkan secara otomatis maupun manual. Tindakan pencegahan dampak negatif akses internet secara nonteknis yang dilakukan pihak Pondok Pesantren adalah dengan melakukan pengarahan kepada santri. Pengarahan diberikan baik pada jam mata pelajaran khusus komputer maupun pada saat pengarahan dari pimpinan Pondok Pesantren atau para pengajar. Ust. Abu Mansyur, pengelola dan penanggung jawab laboratorium komputer dan infrastruktur IT Pondok Pesantren Hidayatullah mengatakan (11/4/2011), bahwa untuk mencegah dampak negatif pemanfaatan internet dan perkembangan teknologi secara umum, santri dibekali mengenai hal tersebut melalui pengarahan-pengarahan dari pimpinan Pondok Pesantren dan juga para pengajar di kelas.

Pengarahan meliputi sikap dan etika dalam menghadapi pesatnya perkembangan teknologi khususnya perkembangan teknologi internet yang tidak dapat dihindarkan. Pada saat mata pelajaran komputer di kelas, selain diajarkan materi-materi teknis, santri juga dibekali dengan pengetahuan dampak negatif internet serta etika saat berinteraksi dengan internet. Hal serupa juga dilakukan pada Pondok Pesantren Amanatul Ummah yang menyediakan akses internet untuk para santri. Ust. Muthiullah, pengasuh Pondok Pesantren Amanatul Ummah menyampaikan (13/4/2011), bahwa santri mendapatkan ceramah mengenai etika melalui ceramah rutin dan pengarahan langsung dari pimpinan Pondok Pesantren. Materi ceramah sangat beragam termasuk mengenai etika dan pembekalan etika santri menghadapi adanya dampak negatif internet. Hal ini dilakukan agar para santri dapat terhindar dari risiko akibat dampak negatif internet dan para santri tidak terjerumus kearah perbuatan yang negatif. Pemahaman mengenai dampak negatif internet juga diperkaya pada saat santri mendapatkan mata pelajaran komputer di kelas atau di laboratorium komputer.

Kiat-kiat lainnya untuk menghindari dampak negatif pemanfaatan internet di kalangan santri Pondok Pesantren disampaikan oleh KH. M. Ali Maghfur Sadzily (12/4/2011). Beliau menyampaikan, pemerintah atau pihak yang terkait serta 
berkepentingan dalam gerakan pemanfaatan internet secara sehat perlu memberikan pemahaman kepada para ustaz (pengajar) Pondok Pesantren tentang pemanfaatan internet secara sehat. Pemahaman tersebut ditujukan agar para ustaz dapat memberikan pemahaman lebih lanjut kepada para santri bahwa internet itu banyak manfaatnya, namun ada pula sisi negatifnya. Oleh karena itu santri perlu dibekali pengetahuan mengenai pencegahan dampak negatif internet. Selain itu para ustadz perlu mengarahkan agar para santri dapat semaksimal mungkin mengupayakan menghindari diri untuk melakukan searching (pencarian melalui internet) terhadap situs-situs yang tidak bermanfaat. Beliau juga menambahkan bahwa dampak negatif pemanfaatan internet di kalangan santri dan masyarakat pada umumnya adalah masalah moral. Untuk menghindari adanya dampak negatif pemanfaatan internet, perlu adanya pembekalan etika. Permasalahan etika lebih lanjut dibahas secara lengkap dalam pendidikan agama atau dengan pendekatan rohaniah. Jika para santri memahami dengan benar etika, moral, dan akhlak yang diajarkan agama Islam dan benar-benar menerapkan dalam kehidupan sehari-hari, maka hal ini dapat menjadi benteng bagi para santri yang memanfaatkan internet untuk dapat memanfaatkan internet secara sehat dan aman.

\section{PENUTUP}

\section{Simpulan}

Keberadan teknologi internet saat ini telah dimanfaatkan di kalangan Pondok Pesantren terutama Pondok Pesantren dengan pola pendidikan modern dan Pondok Pesantren dengan pola pendidikan kombinasi antara Pondok Pesantren modern dan Salafi. Lingkungan pendidikan Pondok Pesantren merupakan lingkungan religius yang selalu mengkedepankan akhlak dan moral berdasarkan tuntunan agama Islam. Keberadaan internet di lingkungan pendidikan Pondok Pesantren juga tetap memiliki dua sisi, yaitu sisi positif dan sisi negatif. Sisi positif pemanfaatan internet atau pemanfaatan internet secara sehat di lingkungan Pondok Pesantren adalah dengan memberdayakan internet untuk kepentingan operasional Pondok Pesantren. Kebutuhan operasional tersebut yaitu untuk mendukung kegiatan belajar-mengajar santri dan mendukung kegiatan yang bersifat administratif bagi pengelola Pondok Pesantren, seperti pertukaran data secara elektronis melalui surat elektronis, sumber referensi pendidikan (perpustakaan digital), sarana penyebaran informasi mengenai Pondok Pesantren hingga sarana dakwah/syiar secara digital.

Di sisi lain, dampak negatif pemanfaatan internet di kalangan Pondok Pesantren juga tidak dapat dihindarkan. Dampak negatif tersebut adalah adanya akses situs-situs pornografi yang dikhawatirkan akan dapat merusak moral para santri. Selain itu beberapa fasilitas hiburan yang dihadirkan oleh internet, yaitu game online dan situs jejaring sosial juga dapat membuat para santri menjadi kecanduan (ketagihan). Keberadaan fasilitas tersebut mengakibatkan santri menjadi lalai sehingga dapat mengakibatkan turunnya prestasi belajar mereka.

Adanya dampak negatif pemanfaatan internet di kalangan santri Pondok Pesantren, menuntut keseriusan pihak pengasuh dan pengelola Pondok Pesantren untuk mencegah timbulnya akibat dari dampak negatif tersebut. Berdasarkan hasil pengamatan pada beberapa objek Pondok Pesantren di Kota Surabaya, terdapat beragam respon para pengasuh dan pengelola Pondok Pesantren mengenai hal tersebut baik secara teknis maupun nonteknis. Secara teknis, ada pihak pengelola yang telah merancang sistem keamanan akses internet sebaik mungkin, ada yang membatasi akses internet, bahkan ada pula yang menghentikan akses internet untuk para santri selama di lingkungan Pondok Pesantren dan juga ada yang melarang penggunaan internet bagi para santri selama bermukim di Pondok Pesantren.

\section{Saran}

Penanggulangan dampak negatif 
internet di kalangan santri dapat dilakukan dengan pemberlakuan kebijakan yang ketat dalam penggunaan internet. Di samping itu pengelola harus terus memperbaharui pengetahuan mereka tentang perkembangan teknologi informasi khususnya perkembangan internet. Pembekalan pengetahuan mengenai dampak positif dan negatif internet perlu diberikan kepada para santri diiringi dengan pembekalan nilai-nilai relijius dan norma serta etika. Kontrol ketat diharapkan agar tidak mematahkan kreativitas para santri akan tetapi mendorong para santri untuk berprestasi dengan memanfaatkan internet.

Dalam konteks pencegahan dampak negatif internet melalui program internet sehat di masyarakat luas, pemerintah juga dapat melakukan berbagai macam pendekatan baik teknis maupun nonteknis. Pemerintah dapat menyosialisasikan berbagai program content filtering seperti; DNS Nawala, dan Net Support. Disamping itu agar sosialisasi program internet sehat dapat dilakukan dengan efektif dan tepat sasaran, pemerintah juga dapat menempuh pendekatan lain dengan menanamkan nilai-nilai religius kepada masyarakat seiring dengan memberikan pengetahuan tentang bahaya dampak negatif internet. Pendekatan tersebut akan lebih efektif dengan melibatkan peran serta pemuka agama untuk turut serta menyosialisasikan bahaya dampak negatif internet yang harus dihindari dengan pembekalan nilai-nilai agama serta norma dan etika yang luhur kepada masyarakat.

\section{DAFTAR PUSTAKA}

Direktorat e-Business. Ditjen APTEL Depkominfo. (2009). Laporan Pelaksanaan Warmasif Trust, Jakarta: Depkominfo,

Direktorat SIPLK. Ditjen APTEL Depkominfo. (2008). Panduan Topologi \& Keamanan Sistem Informasi.Jakarta: Depkominfo,

Griffin. EM. (2003). A First Look At Communication Theory, Fifth Edition, New York: McGraw-Hill.
Isnaini, Muhammad. (2009). Pendidikan Islam Dalam Konteks Pasar dan Pemberdayaan Ekonomi Masyarakat: 'Studi Peran Pesantren Salafiyah dan Modern di Indonesia', Jurnal Pembangunan Manusia, Palembang.

Purbo. Ono W. (2003). Mengenal Teknologi Informasi, Jakarta: Elex Media Komputindo.

Purbo. Onno W \&Wahyudi. Aang Arif. (2001). Mengenal e-Commerce, Jakarta: Elex Media Komputindo.

Singelton, R.A. \& Straits, B. C. (1999). Approaches to Social Research, OUP, New York, (pp. $320-356$ and pp. 513 - 536.)

Zamakhsyari Dhofier, Tradisi Pesantren: Studi Tentang Pandangan Hidup Kiyai, Jakarta, LP3ES

UNESCO. (2006). Declaration of Media Education 